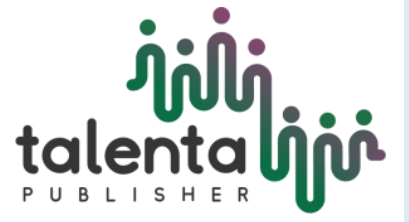

International doupmal of Ecophysiology

\title{
Analysis of Heavy Metals in Coral Fish Species in Sea Natural Reserves of Krakatau Islands
}

\section{Sri Murwani', Eka Prasetiawati ${ }^{1}$, Endang Linirin Widiastuti ${ }^{1,3}$, Supriyanto', Ida Farida Rivai ${ }^{1}$}

1 Department of Biology, 2 Department of Chemistry - Faculty of Mathematics and Natural Sciences, 3 Coastal and Marine Research-LPPM-University of Lampung Corresponding

\begin{abstract}
Krakatau Islands is an area of Nature Reserve and Marine Nature Reserve which has volcanic activity, because of the existence of Gunung Anak Krakatau which is active every year. Volcanic ash erupted contains potentially hazardous chemicals in the form of heavy metals. Heavy metals that enter into waters at a certain level can cause pollution which endangers the lives of biota and disrupt other natural resources in marine ecosystems. This study aims to determine the concentration of heavy metals $\mathrm{Pb}, \mathrm{Ni}, \mathrm{Cd}, \mathrm{Cr}$, $\mathrm{Fe}, \mathrm{Mn}, \mathrm{Zn}, \mathrm{Co}$, and $\mathrm{Ag}$ in reef fish species in the Krakatau Islands. Fish sampling was carried out at three points, namely Anak Krakatau Island, Panjang Island and Rakata Island. The number of individuals obtained was 9 individuals consisting of 5 families, 5 genera and 7 species. Samples of Coral fish were analyzed using Inducible Coupled Plasma Optical Emission Spectrophotometry (ICP-OES - ThermoFishers Scientific). The Pb concentrations in $P$. vittatus, $S$. virgatus, $S$. schlegeli and A. xanthopper have exceeded the quality standard values set by FAO. The highest concentration of $\mathrm{Ni}$ metal is found in P. vittatus and $\mathrm{Cd}$ in all reef fish species that have exceeded the quality standard. Excepted for S.virgatus, Co in all species is above the quality standard value of $0.1 \mathrm{mg} / \mathrm{kg}$. Meanwhile, for all species obtained the concentrations of $\mathrm{Cr}, \mathrm{Mn}, \mathrm{Fe}$ and $\mathrm{Zn}$ did not exceed the standard quality values. The type of metal contained in Z. cornutus, the highest is Fe with a value of 14,427 $\mathrm{mg} / \mathrm{kg}$ and the lowest is Co with a value of $0.099 \mathrm{mg} / \mathrm{kg}$.
\end{abstract}

Keywords: Heavy metals, reeffish, Krakatau, ICP-OES

Received 1 June 2019 | Revised 20 August 2019| Accepted 31 August 2019

\section{Introduction}

Krakatau Islands and its waters are nature reserves and marine reserves located in the Sunda Strait, located between Java and Sumatra. The archipelago consists of small islands which include Anak Krakatau Island, Little Krakatau Island (Panjang), Sertung Island, and the big Krakatau Island (Rakata) (BKSDA, 2012). The Ministry of Energy and Mineral Resources (ESDM) (2014) reported that Mount Anak Krakatau was recorded from October 10, 2010, experiencing ash eruptions accompanied by throwing incandescent material with smoke heights

\footnotetext{
*Corresponding author at: University of Lampung, Lampung, Indonesia

E-mail address: elwidi@yahoo.com
} 
ranging from 100-1700 m and taking place every day until now. According to Wahyuni et al (2012), volcanic ash from the eruption of Mount Merapi contains several major elements in the form of $\mathrm{Si}, \mathrm{Al}, \mathrm{Ca}, \mathrm{Fe}, \mathrm{K}, \mathrm{Mg}, \mathrm{Mn}, \mathrm{Na}, \mathrm{P}, \mathrm{Ti}$ and minor elements in the form of $\mathrm{Ba}, \mathrm{Co}, \mathrm{Cr}, \mathrm{Cu}$, $\mathrm{Pb}, \mathrm{Sr}, \mathrm{Zn}$, and $\mathrm{Zr}$. In addition, there are other dangerous metal elements such as $\mathrm{As}, \mathrm{Cd}$, and $\mathrm{Ni}$.

Heavy metals are pollutant chemicals that are difficult to degrade when entering into waters and in certain concentrations can cause pollution. Heavy metals are classified into two types, namely essential and non-essential heavy metals. Essential heavy metals are metals whose presence in a certain amount is needed by living organisms, but in excessive amounts can cause toxic effects. Examples of this type of metal are $\mathrm{Zn}, \mathrm{Cu}, \mathrm{Fe}, \mathrm{Co}$, and $\mathrm{Mn}$. Whereas nonessential heavy metals are metals whose benefits are unknown or even toxic, such as $\mathrm{Hg}, \mathrm{Cd}$, and $\mathrm{Cr}$ (Putra, 2006).

In aquatic systems, hazardous heavy metals can accumulate biologically through the food chain. Bioaccumulation is different from other processes because it can increase the concentration of toxicity, and not dilute it (Menzer \& Nelson, 1986).Bioaccumulation involves several things, namely the taking of toxic compounds directly by organisms from the waters through gills or epithelial tissue and extraction through food or sediment intake (Katagi, 2010). Pollutants will enter food webs through plankton in water. Plankton that already contains residues of pollutants will be consumed by small fish and thus the concentration of pollutants will increase. This will occur continuously and through the bioaccumulation process will increase the concentration of pollutants at the top trophic level in the waters, namely fish. The contaminated fish when consumed by humans will cause health problems (Goyer, 1986). Coral fish are the largest number of organisms and are also large, striking organisms that can be found on coral reefs (Nybakken, 1992). Reef fish are divided into three main groups, including target fish commonly consumed by humans, indicator fish that typically inhabit coral reefs, and major fish known as ornamental fish. Besides being easily found because of its abundant amount, reef fish is also one of the top predators in the food chain that has the potential to accumulate heavy metals. For this reason, it is considered necessary to conduct research on the analysis of heavy metals in reef fish species.

\section{Materials and Methods}

\subsection{Time and place}

This research was conducted from April - December 2017 in the Krakatau Islands Marine Nature Reserve. The heavy metal analysis was carried out at the Integrated Laboratory Unit and Technology Innovation Center, University of Lampung.

\subsection{Materials used}


The materials used in the study are small boats and boat, GPS (Global Positioning System), diving equipment, sample bags, bottled mineral water, 76\% nitric acid (HNO3), aquabidest, plastic, speargun, Inductively Coupled Plasma Optical Emission Spectrophotometry (ICP-OES Thermo fisher Scientific), pH stick, Thermometer, Refractometer, Sechi-disc, and cool box.

\subsection{Sampling of Coral Fish}

Sampling of coral reef fish was carried out at three points, namely in the waters of Anak Krakatau Island with coordinates $06^{\circ} 06^{\prime} 02.1$ "LS and $105^{\circ} 26^{\prime} 02.4^{\prime \prime}$ BT, in Pulau Panjang waters with coordinates $06^{0} 04^{\prime} 56.6$ "LS and $105^{\circ} 27^{\prime} 21.4 "$ BT, and in Island waters Rakata with coordinates $06^{\circ} 08^{\prime} 47.4$ "and $105^{\circ} 27^{\prime} 45.2^{\prime \prime}$ BT (Figure 1). Samples of coral reef fish were taken using speargun then put in a sample bag. Then, the sample is put into a cool box that already contains ice.

\subsection{Coral Fish Sample Preparation}

The meat samples of coral fish were washed with distilled water 3 times, then the samples were weighed as much as 2 grams and put in a test tube, then $6 \mathrm{ml}$ of $76 \%$ HNO3 was added and wet destructed at $15^{\circ} \mathrm{C}$. After that, the solution obtained is diluted with aquabidest to a volume of 25 ml. Samples are ready to be analyzed using Inductively Coupled Plasma Optical Emission

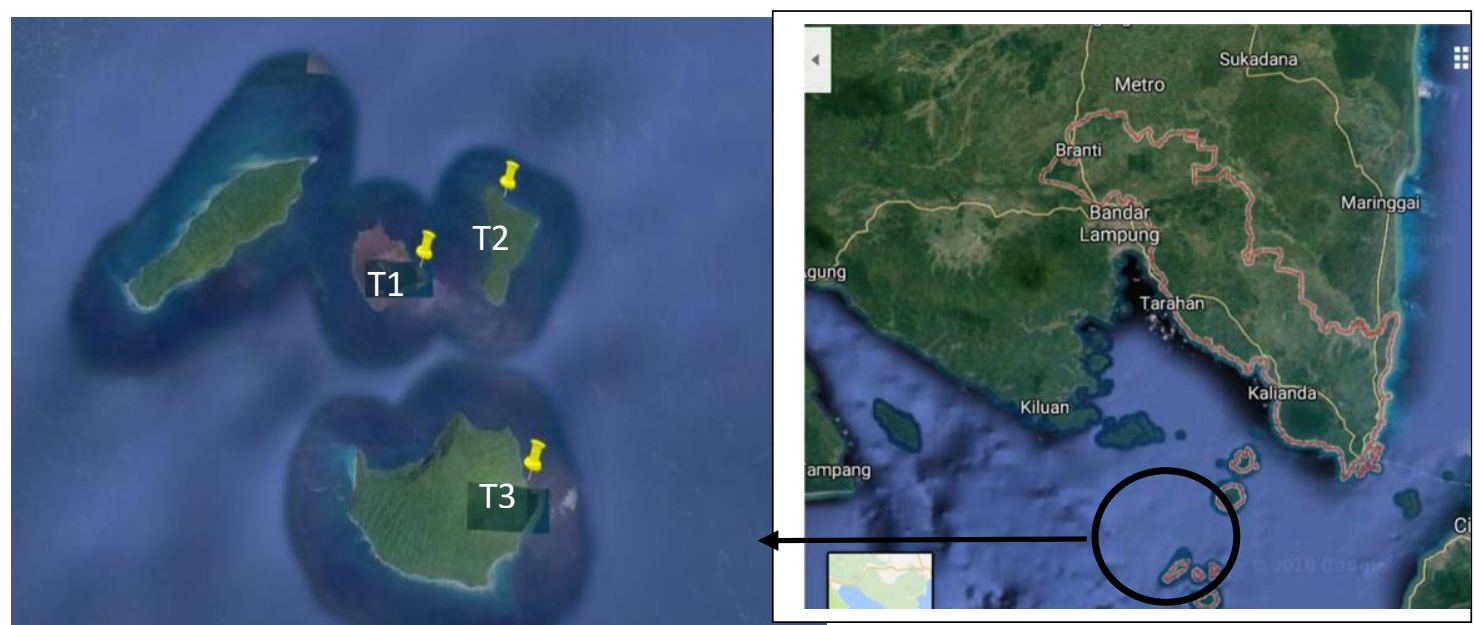

Spectrophotometry (ICP-OES - Thermo fisher Scientific).

Figure 1. Sampling locations in the Krakatau Islands waters - South Lampung

\subsection{Data analysis}

The results of heavy metal analysis on reef fish in the waters of Anak Krakatau Island, Pulau Panjang, and Rakata Island were analyzed descriptively by comparing the concentrations of heavy metals Cadmium (Cd), Nickel (Ni), Chromium ( $\mathrm{Cr}$ ), Lead (Pb), Iron (Fe ), Manganese 
(Mn), Zinc (Zn) Cobalt (Co) and Silver (Ag) with the Standard Criteria for Heavy Metal Quality in Fish from FAO (1983).

\section{Result and Discussion}

The results of sampling of coral fish at the research site were processed as many as 9 individuals consisting of 5 families, 5 genera and 7 species (Table 1). Acanthuridae family obtained consists of Acanthurus sohal, Acanthurus xanthopterus, and Acanthurus nigricans. While Siganus virgatus belongs to the family of siganidae, Plectorhincus vittatus belongs to the family Haemulidae. The Scarus schlegeli belongs to the Scaridae family, and Zanclus cornutuss belongs to the Zanclidae family. The five identified species belong to the target fish group and ornamental fish. Target fish are commonly consumed by humans including A. sohal, S. virgatus, A. xanthopterus, P. vittatus, S. schlegeli, and A. nigcrinacans. While those included in ornamental fish are Z. cornutus.

Table 1. Coral fish samples were obtained at the study site

\begin{tabular}{llccc}
\hline Family & Species (n) & T1 & T2 & T3 \\
\hline Acanthurus sohal (1) & + & - & - \\
Acanthuridae & Acanthurus xanthopterus (2) & - & + & - \\
& Acanthurus nigricans (1) & - & - & + \\
Siganidae & Siganus viragatus (1) & & & \\
Scaridae & Scarus schlegeli (2) & + & - & - \\
Haemulidae & Plectorhincus vittatus (1) & & & \\
Zanclidae & Zanclus cornutuss (1) & - & + & + \\
& & & & + \\
& & - & - & + \\
\end{tabular}

: n: Number of individuals; +: present; - : not present

The results of heavy metal concentrations in Plectorhinchus vittatus, Siganus virgatus, Scarus schelegli, Ancathurus sohal, and Acanthurus nigricans were compared with heavy metal quality standards in fish according to FAO (1983), WHO (1989), WHO (1985), FAO / WHO, and IAEA -407 (Table 2). The metal lead $(\mathrm{Pb})$ concentration in P. vittatus, S. schlegeli, $S$. virgatus, and A. xanthopterus has exceeded the quality standard according to (FAO, 1983). While the $\mathrm{Pb}$ concentration in other species is still below the quality standard (Table 2). Accumulation of lead in high doses in the human body can cause anemia, disruption of iron metabolism and globin synthesis in red blood cells, inhibit the activity of enzymes needed for 
haem synthesis and disorders of the digestive system, kidneys and nervous system (Widowati et al., 2008) . In fish, lead can cause a decrease in survival, growth, development, behavior, and metabolism, and increase mucus formation (Eisler, 1988; 1998). Plectorhincus vittatus has the highest $\mathrm{Ni}$ concentration with a value that has exceeded the range of quality standards according to WHO (1985), which is $1,060 \mathrm{mg} / \mathrm{kg}$. Meanwhile, the Ni concentrations contained in $A$. sohal, S. virgatus, S. schlegeli are still in the range of quality standards and in A. xanthopterus and A. nigricans are still below the range of quality standards (Table. 2). Nickel is a nonessential heavy metal that has cumulative toxins, namely poisons arising from the accumulation of sufficient amounts of nickel metal in the body of living things. The toxic value of nickel in aquatic organisms varies depending on water hardness, $\mathrm{pH}$ and organic matter content, such as other environmental monitor parameters (Sanusi, 2009). Nickel has a negative impact on health, especially if the level has exceeded the threshold (Haspari, 2008). In humans, continuous accumulation of nickel can cause lung cancer, nose cancer, laryngeal cancer, and prostate cancer, damage kidney function, cause loss of balance, cause respiratory failure, birth defects, cause asthma and bronchitis and damage the liver (Mardin, 2011). Cadmium is a non-essential heavy metal that has no role in the biological processes of living things. At low concentrations, cadmium can harm living organisms (Tsui and Wang, 2004). The concentration of metal cadmium (Cd) in all reef fish species in this study has exceeded the level set by FAO (1983) (Table 2). Bioaccumulation of $\mathrm{Cd}$ in fish can cause toxic effects in the form of calcium deficiency (hypocalcemia) that is by inhibiting calcium extraction from water (AMAP, 1998). If the fish is consumed by humans, it can continuously cause health problems. The effects of acute Cd toxicity on humans can cause local irritation in the digestive tract such as nausea, vomiting, diarrhea and abdominal pain. While long-term exposure can cause obstructive pulmonary disease, emphysema, and renal tubular damage. In addition, cadmium can also cause bone deformation (Godt et al., 2006; Gad, 2005).

The concentration of cobalt (Co) in A. sohal, A. xanthopterus, P. vittatus, and A. nigricans has exceeded the quality standard. Meanwhile, Co concentration on S. virgatus has reached the value of the quality standard of $0.099 \mathrm{mg} / \mathrm{kg}$ (Table 2). The study of the acute toxic effects of cobalt metal on marine fish has not been widely documented. In humans, chronic Co exposure has been shown to induce pathology similar to chronic hypoxia and mountain sickness, including cardiomyopathy, increased hemoglobin concentration, and polycythemia as indicated by several types of fish (Wood et al, 2012). The concentrations of $\mathrm{Cr}, \mathrm{Fe}, \mathrm{Mn}$ and $\mathrm{Zn}$ in all reef fish species are still below the quality standard values set by WHO (1989), WHO / FAO (2011), and WHO / FAO (1989) (Table 2). Chromium metal (Cr) is an important nutrient needed in carbohydrate metabolism, but at higher concentrations, it can be toxic (Solomon, 2008). The highest concentration of $\mathrm{Cr}$ is found in $\mathrm{S}$. virgatus with a value of $0.472 \mathrm{mg} / \mathrm{kg}$. Iron has an important role in the process of cytochrome enzyme oxidation and respiratory pigment (hemoglobin) (Hasbi, 2007). The highest concentration of iron $(\mathrm{Fe})$ is found in A. nigricans 
which is $23,265 \mathrm{mg} / \mathrm{kg}$. Among other species, A. nigricans contains Mn concentration the highest is $0.766 \mathrm{mg} / \mathrm{kg}$ (Table 2). This metal plays an important role in the growth and metabolic processes and is one of the important components of the enzyme (Effendi, 2003). Zinc $(\mathrm{Zn})$ is one of the microminerals with functions and uses that are important for the body. $\mathrm{Zn}$ is needed by various organs, such as the skin, mucosa of the digestive tract and almost all cells need $\mathrm{Zn}$ (Underwood, 2001). The important role of $\mathrm{Zn}$ is related to cell activity, gene expression, protein synthesis, and also plays a role in maintaining immune cell activity (Prasad et al., 2007). The highest metal zinc ( $\mathrm{Zn}$ ) concentration is found in P. vittatus, which is 10,529 $\mathrm{mg} / \mathrm{kg}$.

Table 2. The average concentration of heavy metals in reef fish species in Kep. Krakatau

\begin{tabular}{|c|c|c|c|c|c|c|c|c|c|}
\hline \multirow[t]{2}{*}{ Species } & \multicolumn{9}{|c|}{ Average metal concentration $(\mathrm{mg} / \mathrm{kg})$} \\
\hline & $\mathbf{P b}$ & $\mathbf{N i}$ & Cd & $\mathrm{Cr}$ & $\mathbf{F e}$ & Mn & $\mathbf{Z n}$ & Co & Ag \\
\hline $\begin{array}{l}\text { Acanthurus } \\
\text { sohal }\end{array}$ & 0.203 & 0.669 & 0.108 & 0.007 & 1.743 & 0.409 & 4.305 & 0.278 & -0.567 \\
\hline Siganus virgatus & 0.942 & 0.638 & 0.065 & 0.472 & 8.664 & 0.300 & 5.675 & 0.067 & -0.525 \\
\hline Scarus schlegeli & 1.670 & 0.517 & 0.126 & 0.212 & 15.694 & 0.611 & 7.277 & 0.137 & -0.558 \\
\hline $\begin{array}{l}\text { Acanthurus } \\
\text { xanthopterus }\end{array}$ & 0.730 & 0.195 & 0.106 & 0.117 & 8.477 & 0.445 & 8.012 & 0.123 & -0.596 \\
\hline $\begin{array}{l}\text { Plectorhincus } \\
\text { vittatus }\end{array}$ & 1.935 & 1.060 & 0.153 & 0.128 & 7.835 & 0.428 & 10.529 & 0.135 & -0.605 \\
\hline $\begin{array}{l}\text { Zanclus } \\
\text { cornutus }\end{array}$ & 0.121 & 0.467 & 0.103 & 0.115 & 14.427 & 0.436 & 6.548 & 0.099 & 0.992 \\
\hline $\begin{array}{l}\text { Acanthurus } \\
\text { nigricans }\end{array}$ & 0.362 & 0.249 & 0.203 & 0.130 & 23.265 & 0.766 & 8.204 & 0.196 & -0.559 \\
\hline Quality Standarc & & & & & & & & & \\
\hline FAO (1983) & 0.5 & - & 0.05 & 1.00 & - & - & 30 & - & - \\
\hline
\end{tabular}




\begin{tabular}{|c|c|c|c|c|c|c|c|c|c|}
\hline WHO (1985) & 2.0 & $0.5-0.6$ & 2.0 & - & - & - & - & - & - \\
\hline FAO/WHO & 0.5 & - & 0.5 & - & - & 5.5 & 40 & - & - \\
\hline IAEA-407 & 0.12 & 0.6 & 0.19 & 0.73 & 146 & 3.52 & 67.1 & 0.1 & 0.037 \\
\hline \multicolumn{10}{|l|}{ (2003) } \\
\hline WHO (1989) & 2 & - & 1 & - & 100 & 1 & 30 & - & - \\
\hline LOD & 0.955 & 2.589 & 0.811 & 1.129 & 0.509 & 0.921 & 0.654 & 2.491 & 0.657 \\
\hline LOQ & 3.183 & 8.632 & 2.703 & 3.762 & 1.696 & 3.070 & 2.179 & 8.304 & 2.188 \\
\hline
\end{tabular}

Description: LOD: Limited of Detection; LOQ: Limited of Quantity Z. cornutus is known as marine ornamental fish whose life is also very dependent on coral reefs. The highest concentration of heavy metals in this section is Fe with a value of $14,427 \mathrm{mg} / \mathrm{kg}$ and the lowest is Co with a value of $0.099 \mathrm{mg} / \mathrm{kg}$.

The mean of heavy metals $\mathrm{Pb}, \mathrm{Cd}$, and $\mathrm{Co}$ in reef fish species in all study locations has exceeded the quality standard. Meanwhile, the highest average of heavy metals in reef fish species in the study location is generally Fe (Table 3). Mount Anak Krakatau can be the main source of the presence of heavy metals in these waters. Volcanic ash produced by volcanic eruptions contains several heavy metals, both major and minor. Based on the results of research conducted by Wahyuni (2012) regarding the composition of volcanic ash from the eruption of Mount Merapi that $\mathrm{Fe}$ is one of the major metals supplied by Mount Merapi with a high level of 9.17\%. This is also in accordance with research conducted by Hanuun (2017), that sediments on Anak Krakatau island, Pulau Panjang, and Rakata Island already contain very high levels of Fe metal with successive values of $0.743 \%, 0.514 \%$, and $0.753 \%$. The concentration of heavy metals in the body of marine life, such as fish, has a positive correlation with the concentration of heavy metals found in sediments, as shown in several types of mollusks in the waters of the Mediterranean sea (Abdallah, 2013). In addition, the distribution of pollutants and accumulation of heavy metals in the waters of the Krakatau Islands is influenced by currents and turbulence mixtures (Bahri, 2003) in the Sunda Strait. 
Table 3. Average heavy metals in the waters of the Krakatau Islands Marine Reserve

\begin{tabular}{cllllllllll}
\hline \multirow{2}{*}{ Location } & \multicolumn{10}{c}{$(\mathbf{m g} / \mathbf{k g})$} \\
& $\mathbf{P b}$ & $\mathbf{N i}$ & $\mathbf{C d}$ & $\mathbf{C r}$ & $\mathbf{F e}$ & $\mathbf{M n}$ & $\mathbf{Z n}$ & $\mathbf{C o}$ & $\mathbf{A g}$ \\
& & & & & & & & & \\
\hline $\mathrm{T} 1$ & 0.68 & 0.626 & 0.094 & 0.229 & 7.69 & 0.475 & 5.648 & 0.149 & -0.561 \\
$\mathrm{~T} 2$ & 1.131 & 0.483 & 0.121 & 0.120 & 8.268 & 0.439 & 8.851 & 0.127 & -0.559 \\
$\mathrm{~T} 3$ & 0.976 & 0.393 & 0.149 & 0.153 & 18.806 & 0.569 & 7.412 & 0.155 & -0.031 \\
\hline
\end{tabular}

All marine organisms such as fish are strongly influenced by environmental factors such as temperature, $\mathrm{pH}$, salinity, and brightness. These various natural factors play an important role in the ability to move and process the physiology of living things in the waters. In addition, the quality of seawater also greatly determines the solubility and toxicity of a heavy metal. Temperature is a very important factor in regulating life processes and the spread of organisms, as well as metabolism in the body of living things (Azwar et al., 2016). The measured temperature at the study site shows an average value of $29{ }^{\circ} \mathrm{C}$. This value is still within the range set by the Decree of the Minister of Environment No. 51 of 2004, namely $28-30{ }^{\circ} \mathrm{C}$. Whereas the $\mathrm{pH}$ value and salinity of seawater at the research location are already below the range of values set by the Minister of Environment LH No. 51 of 2004. The pH value obtained is 6 with the range set 7-8.5 and the salinity value obtained is $30 \%$ with a set range of 33-34 $\%$. Decreasing $\mathrm{pH}$ and salinity of seawater can cause greater heavy metal toxicity (Rochyatun \& Rozak, 2007; Hutagalung, 1991). Brightness is a condition that shows the ability of light to penetrate the water layer at a certain depth (Effendi, 2003). Based on the results of measurements at the study site, it still shows brightness at a depth of 25 meters. This shows that the penetration of light in the waters of Krakatau is still very good so photosynthetic activity is still running optimally.

\section{Conclusions}

Based on the results of the research obtained it can be concluded that the concentrations of heavy metals $\mathrm{Pb}, \mathrm{Ni}, \mathrm{Cd}$, and $\mathrm{Co}$ in $A$. sohal, S. virgatus, S. schlegeli, P. vittatus, $A$. xanthopterus, and A. nigricans have exceeded the quality standard. Meanwhile the highest heavy metals in Z. cornutus were Fe with a value of $14,427 \mathrm{mg} / \mathrm{kg}$ and the lowest was Co with a value of $0.099 \mathrm{mg} / \mathrm{kg}$.

\section{Acknowledgment}


Our thanks to the Natural Resources Conservation Center (BKSDA - Bengkulu) - resort Lampung for the facilities provided in this study. We also thank the Research and Community Service Institute of the University of Lampung for funding support in this study.

\section{References}

[1] Abdallah, M. A. M. 2013. Bioaccumulation of Heavy Metals in Mollusca Species and Assessment of Potential Risks to Human Health. Bull Environ Contam Toxicol 90:552557.

[2] Azwar, M., Emiyarti, Yusnaini. 2016. Critical Thermal Dari Ikan Zebrasoma scopas Yang Berasal Dari Perairan Pulau Hoga Kabupaten Wakatobi. Sapa Laut. 1(2): 60-66.

[3] Bahri, S. 2003. Tingkat Kontaminasi Logam Berat Hg dan Pb di Perairan Muara Cunda Lhokseumawe Aceh Utara. Thesis Pasca Sarjana. InstitutPertanian Bogor. Bogor. Balai Konservasi Sumber Daya Alam (BKSDA). 2012. Kepulauan Krakatau.BKSDA Lampung - Lampung.

[4] Effendi, H. 2003. Telaah Kualitas Air. Kanisius. Yogyakarta.

[5] Eisler R. 1988. Lead hazard to fish, wildlife, and invertebrates: A synoptic review. US Fish and Wildlife Service Report 85:1-14.

[6] Eisler R. 1998. Nickel hazard to fish, wildlife, and invertebrates: A synoptic review. Biological Science Report USG/BRD/BSR-1998-0001. Laurel, MD

[7] FAO. 1983. Compilation of legal limits for hazardous substances in fish and fishery products. FAO Fishery Circular No. 464, 764, pp 5-100

[8] Gad, S.C. 2005. Cadmium. Dalam: Encyclopedia of toxicology (Ed. Ke-2, Vol. 1, Halaman 375-377). Elsevier. USA.

[9] Godt, J., Scheidig, F., Grosse-Siestrup, C., Esche, V., Brandenburg, P., Reich, A., and Groneberg D. A. 2006. The toxicity of cadmium and resulting hazard for human health. 10 December 2017. http://www.ncbi.nlm.nih.gov/pmc/articles/PMC1578573/

[10] Goyer, R.A. 1986.Toxic Effect of Metals.In Toxicology. The Basic Science of Poison.Third Edition. Edited by: C.D Klaassen, M.O Amdur \& J. Doull. Macmillan Publishing Company New York.

[11] Hanuun, N.I. 2017. Analisis Logam Berat (Pb, Ni, Cd, Cr, Fe, Mn, Zn, Co, dan Ag) pada Sedimen laut dan foraminifera Bentik di Perairan Cagar Alam Laut Krakatau Provinsi Lampung dengan metode ICP-OES. Skripsi. Universitas Lampung.

[12] Hasbi, R. 2007. Analisis Polutan Logam Tembaga $(\mathrm{Cu})$ dan Timbal $(\mathrm{Pb})$ Dalam Sedimen Laut Pelabuhan Pantoloan Berdasarkan Kedalamannya. (Skripsi). UNTAD Press. Palu.

[13] Haspari. 2008. Pemurnian Nikel (Ni) dan Seng (Zn) dalam pengolahan limbah cair industry elektronik menggunakan Nikel. Thesis. Universitas Gajah Mada - Jogakarta.

[14] Hutagalung, H.P. 1991. Pencemaran Laut Oleh Logam Berat. Puslitbang Osenologi Status Pencemaran Laut di Indonesia dan Teknik Pemantauannya. LIPI. Jakarta. 
[15] Katagi, T. 2010. Bioconcentration, Bioaccumulation, and Metabolism of Pesticides in Aquatic Organism. In D. M. Whitacre, Reviews of Environmental Contamination Toxicology (pp. 1-123). New York: Springer. Doi: 10.1007/978-4419-1440-8_1.

[16] Kementerian Energi dan Sumber Daya Mineral (ESDM) .2014. Gunung Krakatau. http://www.vsi.esdm.go.id. Diakses pada 16 September 2017.

[17] Mardin. 2011. Toksisitas Nikel (Ni) Terhadap Ikan Nila GIFT (Oreochromis-niloticus) Pada Media Berkesadahan Lunak (Soft Hardness). (Tesis). Program Pascasarjana Institut Pertanian Bogor. Bogor.

[18] Menzer, R.E and J.O. Nelson. 1986. Water and Soil Pollutants. In Toxicology. The Basic Science of Poison.Third Edition. Edited by: C.D Klaassen, M.O Amdur \& J. Doull.Macmillan Publishing Company New York.

[19] Nybakken, J. W. 1992. Biologi Laut, Suatu Pendekatan Ekologis (dari Marine Biology: An Ecological Approach. Penerjemah E.H. Muhammad et al., (edisi pertama). PT. Gramedia. Jakarta.

[20] Prasad, A.S., F.W. Beck, B. Baso, J.T. Fitzgerald, D.C. Snell, J.D. Steinberg and L.J.

[21] Cardoso. 2007. Zinc supplementation decreases incidence of infection in the Elderly: Effect of zinc on generation of cytokines and oxidative stress. The American Journal of Clinical Nutrition. 85: 837-844.

[22] Putra, J. A. 2006. Bioremoval, Metode Alternative Untuk Mengangani Pencemaran Logam Berat. http://www.chemistry.org. Diakses pada 09 Oktober 2017.

[23] Rochyatun E dan Rozak A. 2007. Pemantauan Kadar Logam Berat Dalam Sedimen Di Perairan Teluk Jakarta. Makara, Sains. 11(1): 28-36.

[24] Sanusi HS, Putratno S. 2009. Kimia Laut dan Pencemaran, Proses Fisik Kimia dan Interaksi dengan Lingkungan. Departemen Ilmu dan Teknologi Kelautan. Institut Pertanian Bogor.

[25] Solomon, F. 2008. Impact of metals on Aquatic Ecosystem and Human Health, Journal of Environment and Communities.

[26] Tsui M. T. K. and Wang W. V. 2004. Uptake and elimination routes of inorganic mercury And methylmercury in Daphnia manga. Environ.Sci.Techno. 38: 808-816.

[27] Underwood, EJ. And N.F Suttle. 2001. The Mineral Nutrition of Livestock. CABI Publishing. USA.

[28] Wahyuni, E.T., S. Triyono, dan Suherman. 2012. Penentuan Komposisi Kimia Abu Vulkanik Dari Erupsi Gunung Merapi. J. Manusian Dan Lingkungan. 19(2): 150-159.

[29] WHO. 1989. Evaluation of certain food additives and contaminants. 33rd Report of the Joint FAO/WHO expert committee on food additives. Technical Report Series Geneva. Widowati, W., Sastiono, A., Jusuf, R. 2008. Efek Toksik Logam. Penerbit ANDI. Yogyakarta.

[30] Wood, C., A. Farrell, C. Brauner. 2012. Fish Physiology: Homeostasis and Toxicology of Essential Metals. Vol. 31. A . ${ }^{\text {st }}$ Edition. Academic Press - England. 520 pages. 